\title{
Annelid symbiont assemblage and European stone crayfish - a deterministic relationship with implications for conservation management
}

\author{
Christian Berger ${ }^{*}$ and Leopold Füreder \\ River Ecology and Conservation, Institute of Ecology, University of Innsbruck, Technikerstraße 25, 6020 Innsbruck, Austria
}

\begin{abstract}
The protected European stone crayfish, Austropotamobius torrentium, is a host to epibionts inhabiting its exoskeleton. Despite evidence of the close association of these epibionts to the crayfish and the beneficial services provided for the crayfish, the main factors influencing their occurrence, distribution and abundance are still poorly understood. In order to investigate the stone crayfish epibiont community, the ecological requirements of individual species, and aspects of the host-epibiont relationship we collected data at several crayfish populations in Austria, Switzerland and Germany. At each location, we recorded the epibiont position on the crayfish host along with a number of biotic and abiotic parameters. Apart from recording the Branchiobdella species $B$. parasita, B. hexadonta, B. pentadonta and B. balcanica, we detected for the first time the polychaete Hystricosoma chappuisi in the European Alps. Species-specific biogeographical and habitat factors such as river catchment borders, crayfish length, water temperature and nutrients concentration were identified to be important for the occurrence and abundance of epibionts. Branchiobdella species were strongly linked to certain host body areas, providing evidence for the existence of different functional traits within the annelid assemblage. With this study we demonstrate that the crayfish-epibionts relationship includes structural and functional complexities that can be important for defining management units in future conservation policies. Due to benefits for the mutualistic relationship, restocking and reintroduction actions are likely to be more successful, if ecological requirements of both the host and the epibiont species are considered.
\end{abstract}

Keywords: Austropotamobius torrentium / Branchiobdella / Hystricosoma chappuisi / biogeography / aquatic microcosm

\begin{abstract}
Résumé - L'assemblage des annélides symbiotes et l'écrevisse des torrents européenne - une relation déterministe avec des implications pour la gestion de la conservation. L'écrevisse des torrents européenne Austropotamobius torrentium, espèce protégée, est l'hôte d'épibiontes fixés sur son exosquelette. Malgré les preuves de l'association étroite de ces épibiontes aux écrevisses et les services bénéfiques fournis aux écrevisses, les principaux facteurs influençant leur occurrence, leur distribution et leur abondance sont encore mal compris. Afin d'étudier la communauté d'épibiontes de l'écrevisse des torrents, les exigences écologiques des différentes espèces et certains aspects de la relation hôte-épibionte, nous avons recueilli des données sur plusieurs populations d'écrevisses en Autriche, en Suisse et en Allemagne. A chaque endroit, nous avons enregistré la position de l'épibionte sur l'écrevisse ainsi qu'un certain nombre de paramètres biotiques et abiotiques. En plus de l'enregistrement des espèces de Branchiobdelles B. parasita, B. hexadonta, B. pentadonta et B. balcanica, nous avons détecté pour la première fois le polychète Hystricosoma chappuisi dans les Alpes européennes. Des facteurs biogéographiques et des facteurs liés à l'habitat propres aux espèces, tels que les limites des bassins hydrographiques, la taille des écrevisses, la température de l'eau et la concentration des éléments nutritifs, ont été jugés importants pour la présence et l'abondance des épibiontes. Les espèces de Branchiobdelles étaient fortement liées à certaines zones du corps de l'hôte, ce qui permettait de prouver l'existence de différents caractères fonctionnels au sein de l'assemblage des annélides. Avec cette étude, nous démontrons que la relation écrevisse-épibiontes inclut des complexités structurelles et fonctionnelles qui peuvent être
\end{abstract}

\footnotetext{
*Corresponding author: berger_ch@gmx . at
} 
importantes pour la définition des unités de gestion dans les futures politiques de conservation. En raison des avantages de la relation mutualiste, les actions de repeuplement et de réintroduction sont susceptibles d'être plus fructueuses si l'on tient compte des exigences écologiques de l'hôte et des épibiontes.

Mots-clés : Austropotamobius torrentium / Branchiobdelle / Hystricosoma chappuisi / biogéographie / microcosme aquatique

\section{Introduction}

Worldwide, several metazoan taxa (e.g. platyhelminths, nematodes, annelids, arthropods) have been observed to be linked to freshwater crayfish, either as parasites or commensals (Evans and Edgerton, 2002). Among these, in the Holarctic, the leech-like Branchiobdellida (Annelida: Clitellata) have likely been investigated the most. Approximately 140 species and 22 genera have been thus far described, occurring in North and Central America, Europe and Asia (Gelder and Williams, 2015). In Europe only one genus, Branchiobdella, of the subfamily Branchiobdellinae, is autochthonous and consists of eight species (Subchev, 2014).

Despite the ability to survive separated from their hosts for some time (McManus, 1960), Branchiobdellidans are considered to be obligate associates, since they reproduce exclusively on crayfish (Young, 1966; Creed et al., 2015). Recent studies indicate that the relationship between Branchiobdellida and their hosts is highly complex. Due to their larger body surface and lower moulting rate, adult crayfish specimens, for instance, display higher infestation rates than young ones (Scalici et al., 2010; Vedia et al., 2016). Moreover, a link between the Branchiobdellida community and the hosts ontogeny was suggested, as adult North-American crayfish Cambarus sciotensis showed not only a higher Branchiobdellida diversity, but also were inhabited by Branchiobdellida species with larger body sizes than young specimens (Skelton et al., 2016). In female crayfishes, the density of epibionts might vary as a function of reproductive state. Crayfish specimens have in return been observed to actively control the Branchiobdellida density by grooming movements with their claws (Farrell et al., 2014). As young crayfish turned out to be more active and successful in removing the annelids, the grooming efficiency was suggested to vary with the host's ontogeny (Skelton et al., 2016).

While certain Branchiobdellidans were formerly assumed to act as parasites (Holt, 1965; Grabda and Wierzbicka, 1969), more recent studies suggest that they benefit their hosts by feeding on the exoskeleton biofilm (Brown et al., 2002; Vedia et al., 2016). Accordingly, the presence of fungal hyphae in the gut of Branchiobdella italica supported the presumption that this species limits the fungal growth on the hosts exoskeleton or eggs (Scalici et al., 2010). However, depending on the fouling pressure on the host and the Branchiobdellida abundance, the impact is likely to fluctuate between commensalism and mutualism or even parasitism (Lee et al., 2009; Brown et al., 2012).

Despite an increasing number of studies dealing with crayfish-epibionts, the factors influencing the occurrence and abundance of the crayfish worms are still poorly understood. Habitat characteristics such as the water nutrient concentration and water temperature were previously assumed to be relevant for the abundance of Branchiobdellida (Meike, 1999; DeWitt et al., 2013). However, if or to what extent other abiotic factors might also have an influence, has not yet been investigated. Likewise, our knowledge about the potential impact of co-occurring species on the host is scarce, although the occurrence of multiple Branchiobdella species on a single crayfish individual is a common phenomenon (Gelder and Williams, 2011, 2015). In this regard, recent studies indicated that the Branchiobdellida density/diversity as well as the level of interspecific interactions is higher when the symbiosis is advantageous for the host (Skelton et al., 2016).

In Europe, the stone crayfish Austropotamobuis torrentium is one out of five indigenous crayfish species, all of which host some Branchiobdella species. The natural distribution of $A$. torrentium ranges from the Balkans in the southeast (Greece, Romania, Bulgaria, etc.) up to Central Germany and Switzerland in the northwest of Europe (Holdich, 2002; Kouba et al., 2014). For the last decades, the species has undergone an unprecedented decline (Füreder et al., 2006; Holdich et al., 2010; Chucholl and Schrimpf, 2015) and as a result, it is listed in the IUCN Red List (Füreder et al., 2010). Such a negative trend was also stated for Vorarlberg, the western-most federal state in Austria, where an urgent need for species conservation measures has recently been proposed (Berger and Füreder, 2013). In this regard, human-mediated introductions of non-indigenous crayfish species into European inland waters are considered to be a major threat for both the native crayfish (Holdich et al., 2010) and the crayfishbranchiobdellidan relationship. As non-indigenous crayfishes carry exotic Branchiobdellida species, there is not only a competitive interaction between the crustacean invaders and the native crayfishes, but potentially negative effects for the mutualistic crayfish-branchiobdellidan relationship due to the introduction of new crayfish worm species (Vedia et al., 2015; James et al., 2017).

Given the obligate association of Branchiobdellida to freshwater crayfish, the long-term survival of crayfish worms is directly linked to the conservation status of their hosts (Nesemann, 1998). Nevertheless, essential aspects of the distribution and ecological requirements of European Branchiobdella are largely unexplored. Specifically, their distribution has been studied in the river catchments of eastern and southern Europe (e.g. Gelder et al., 1999; Klobučar et al., 2006; Subchev, 2011), whereas only few reports exist about the Rhine catchment (Bohl, 1997; Nesemann and Hutter, 2002). Furthermore, biogeographical links between crayfish and Branchiobdellida distribution have not yet been addressed. Despite indications for a distribution overlap (Füreder et al., 2009), due to the long and complex colonization history of the Central European freshwater crayfish (Trontelj et al., 2005) species-specific distribution patterns of individual epibionts cannot be strictly ruled out. 


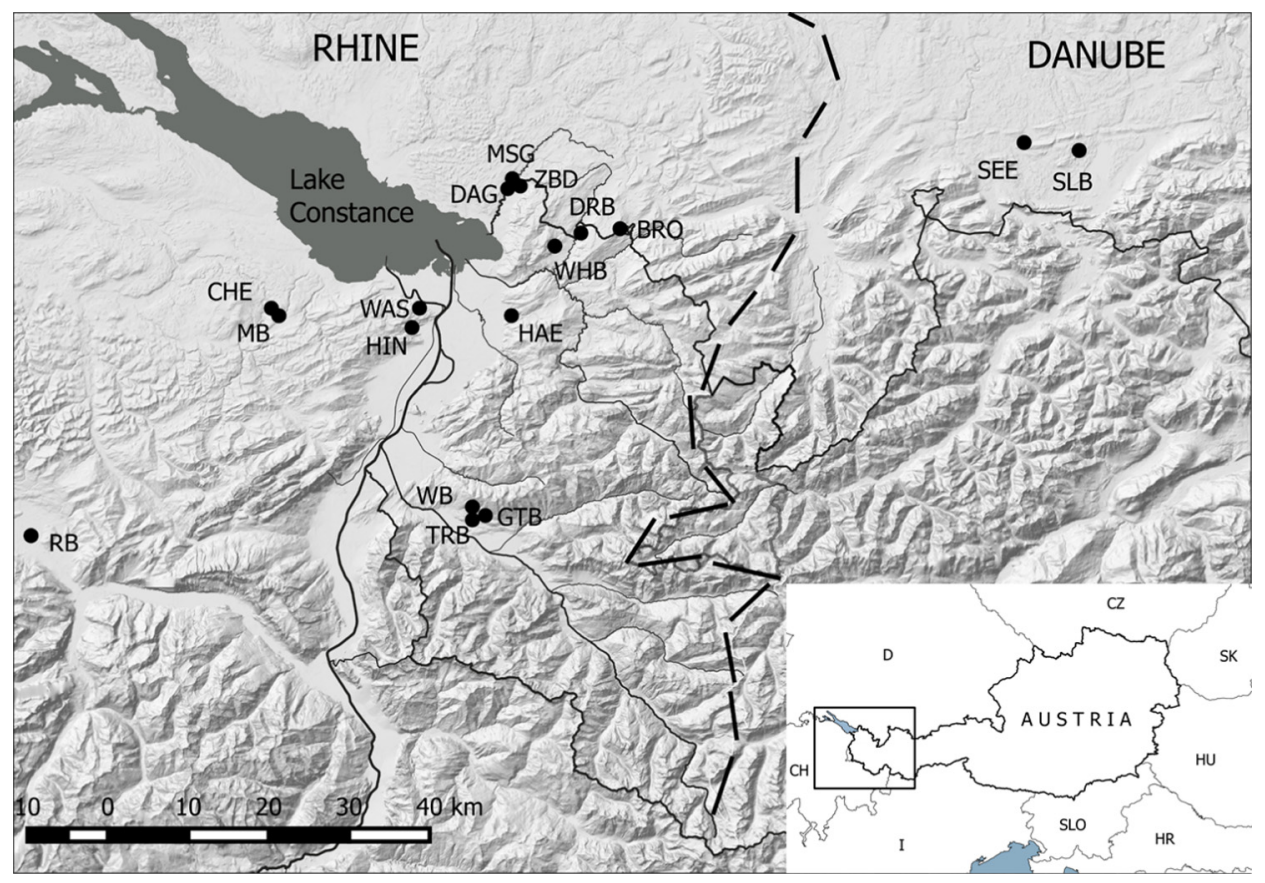

Fig. 1. Study sites and study area (dashed line shows border between Rhine and Danube catchment; for study site abbreviations see Tab. 1).

Compared to the large number of publications addressing the relationship between freshwater crayfish and Branchiobdella species, studies dealing with other epibiotic Metazoa are very scarce. So far, most studies concentrated on a few species of Turbellaria, Nematoda, Acanthocephala and Oligochaeta, which were reported to cause crayfish diseases (Evans and Edgerton, 2002 and references within). Ecological aspects of the relationship between other epibionts and their crayfish hosts have however not been investigated yet. Likewise, no studies have been performed addressing possible co-occurrences of these epibionts with Branchiobdella and the relationship between these taxa. A better understanding of the crayfish-epibionts assemblage deserves however special attention in freshwater crayfish conservation, where translocations of crayfish (restockings, reintroductions) are commonly applied measures. While evaluation of phylogenetic relationships and habitat suitability are meanwhile widely accepted to be essential in crayfish conservation (SoutyGrosset and Reynolds, 2009), the importance of considering epibiont communities in crayfish translocation has received little attention.

In order to address existing knowledge gaps, we designed a study as part of a stone crayfish conservation project, which included the assessment of the distribution and abundance of Branchiobdella and other metazoan epibionts on the stone crayfish in two major European catchment areas (Rhine and Danube). With the aim to identify species-specific habitat requirements, we recorded biotic and abiotic habitat parameters at all study sites and modelled them against species abundances. We hypothesized that (1) stone crayfish populations in the study area are host to diverse epibiont communities, (2) due to the complex colonization history of the host, which was influenced by paleoclimatic and hydrological factors, crayfish epibionts display speciesspecific distribution patterns, (3) the abundance of individual epibiont species varies according to different, species-specific habitat requirements and (4) in addition to environmental preferences, the abundance of individual epibiont species is affected by the abundance of co-occurring species.

\section{Materials and methods}

\subsection{Study area and study site selection}

The study was conducted at the foothills of the European Alps (Fig. 1). The sites in the region of Vorarlberg (western Austria) were sampled in the course of a regional crayfish conservation program (Berger and Füreder, 2013). To investigate the distribution of stone crayfish epibionts on a larger regional scale, additional epibiont samples were taken at five sites in eastern Switzerland and two sites in Bavaria. Austrian and Swiss sites were located in the Rhine catchment area, whereas the Bavarian sites were in the Danube catchment area. These two populations were included with regard to potential distribution differences of epibionts between these main European catchments areas. In total, 17 running waters were sampled where stone crayfish is considered indigenous (Tab. 1). Except at CHE (full names of the localities are given in Tab. 1), where the white-clawed crayfish was co-occurring, the stone crayfish was the only freshwater crayfish species present. Detailed data on sample sizes and sites are provided in Tables S1 and S2.

At the beginning of the study, Branchiobdella species were known to occur in five brooks in Vorarlberg (Nesemann and Hutter, 2002). Among these, records of Branchiobdella parasita (Braun, 1805) exist for all the sites, whereas Branchiobdella hexadonta (Gruber, 1883) and Branchiobdella papillosa (Nesemann and Hutter, 2002) have each been reported at two sites. Of these five brooks, four were included in our study (TRB, WB, DRB, BRO). 
Table 1. Study sites, number (Nr.) and body size of sampled crayfish individuals per site $\left({ }^{*}=\right.$ Austria $\left(\right.$ Rhine),${ }^{* *}=$ Switzerland $($ Rhine), ${ }^{* * *}=$ Germany (Danube)).

\begin{tabular}{|c|c|c|c|c|c|c|c|c|}
\hline \multirow[t]{2}{*}{ Site (abbreviation) } & \multicolumn{8}{|c|}{ Number and body size of crayfish individuals } \\
\hline & $\begin{array}{l}\text { Nr. } \\
\text { (July } \\
2009 \text { ) }\end{array}$ & $\begin{array}{l}\text { Body } \\
\text { size }(\mathrm{cm})\end{array}$ & $\begin{array}{l}\text { Nr. } \\
\text { (Oct/Nov } \\
2009 \text { ) }\end{array}$ & $\begin{array}{l}\text { Body } \\
\text { size }(\mathrm{cm})\end{array}$ & $\begin{array}{l}\text { Nr. } \\
\text { (July } \\
2010 \text { ) }\end{array}$ & $\begin{array}{l}\text { Body } \\
\text { size }(\mathrm{cm})\end{array}$ & $\begin{array}{l}\text { Nr. } \\
\text { (Sept/Oct } \\
2011)\end{array}$ & $\begin{array}{l}\text { Body } \\
\text { size }(\mathrm{cm})\end{array}$ \\
\hline Torfriedbächle (TRB) ${ }^{*}$ & 12 & $5.6-8.4$ & 10 & $5.0-8.7$ & 5 & $6.4-7.7$ & - & - \\
\hline Gandatobelbach (GTB) ${ }^{*}$ & 6 & $5.0-7.9$ & 6 & $6.4-8.0$ & - & - & - & - \\
\hline Walsbächle (WB)* & 12 & $5.5-8.8$ & 10 & $6.1-9.0$ & - & - & - & - \\
\hline Hänslerbach (HAE)* & 12 & $5.4-7.6$ & 10 & $5.5-8.0$ & - & - & - & - \\
\hline Weißenhubenbach (WHB)* & 12 & $6.1-9.6$ & 9 & $8.2-9.8$ & - & - & - & - \\
\hline Dreienauerbach (DRB)* & 12 & $5.7-8.5$ & 10 & $5.9-8.8$ & - & - & - & - \\
\hline Brögergraben (BRO)* & 12 & $6.0-8.6$ & 9 & $8.2-9.6$ & - & - & - & - \\
\hline Dreiangelgraben (DAG)* & 6 & $5.4-7.5$ & 6 & $6.2-9.0$ & 4 & $6.1-9.1$ & - & - \\
\hline Zubringer Dorfbach (ZBD)* & 4 & $5.3-7.4$ & 6 & $5.6-8.2$ & 4 & $5.9-7.2$ & - & - \\
\hline Mühlsteiggraben (MSG)* & 4 & $5.7-7.0$ & 7 & $5.0-8.7$ & 4 & $6.1-8.1$ & - & - \\
\hline Hinterburgbach $(\mathrm{HIN})^{* *}$ & - & - & - & - & - & - & 10 & $5.9-9.5$ \\
\hline Wasenbach (WAS)** & - & - & - & - & - & - & 10 & $7.1-8.6$ \\
\hline Mühlbächli (MB)** & - & - & - & - & - & - & 10 & $6.5-8.9$ \\
\hline Chellenbach $(\mathrm{CHE})^{* *}$ & - & - & - & - & - & - & 10 & $5.1-7.7$ \\
\hline Rietbächli $(\mathrm{RB})^{* *}$ & - & - & - & - & - & - & 10 & $7.4-9.4$ \\
\hline Zubringer Seeg $(\mathrm{SEE})^{* * *}$ & - & - & - & - & - & - & 10 & $5.5-7.8$ \\
\hline Schleichbach (SLB)*** & - & - & - & - & - & - & 10 & $6.0-8.9$ \\
\hline
\end{tabular}

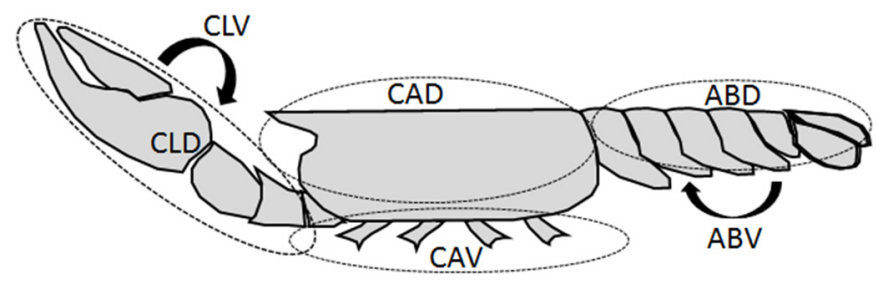

Fig. 2. Crayfish body parts sampled for epibionts (in the abbreviations the first two letters indicate the crayfish body part: $\mathrm{CL}$ - claws, $\mathrm{CA}$ - carapace, $\mathrm{AB}$ - abdomen and the third one: $\mathrm{D}$ - dorsal and $\mathrm{V}$ - ventral).

\subsection{Crayfish and epibiont sampling}

Crayfish samples were taken from 2009 to 2011 (Tab. 1). In Vorarlberg, sampling was performed in July and October/ November 2009 with regard to potential seasonal differences in abundance and species composition. At a few sites (TRB, DAG, ZBD, MSG), additional samples were taken in July 2010. In September/October 2011, epibionts have been sampled on crayfish at the Swiss and German sites only. Exact individual counts of Branchiobdella and Nais communis were performed in both seasons, whereas exact counts of Hystricosoma chappuisi (Michaelsen, 1926) are only available for the autumn samples.

Crayfish were caught by hand at night along a $30-50 \mathrm{~m}$ stretch and held for max. $1 \mathrm{~h}$ in a basket filled with water in groups of 3-4 individuals. The total body length (TL) of crayfish specimens was measured from the tip of the rostrum to the end of the telson in the field using a caliper. All visible Branchiobdella specimens were immediately collected in the field with a forceps. The detected specimens on a crayfish individual were stored separately in tubes with $70 \% \mathrm{EtOH}$ according to their position on the crayfish: claws dorsal (CLD), claws ventral (CLV), carapace dorsal (CAD), carapace ventral (CAV), abdomen dorsal (ABD) and abdomen ventral (ABV) (Fig. 2). In order to also gather small and hidden epibionts, stone crayfish specimens were rinsed in a $5 \% \mathrm{MgCl}_{2}$ solution for $10 \mathrm{~min}$. This salty bath immobilized the epibionts and made them fall off their hosts. These specimens, collected from each crayfish, were put in separate tubes and categorized as the rest of the sample (from here on "R").

\subsection{Species determination}

Epibionts were determined using a Leica Wild M 10 dissecting microscope $(80 \times)$ (Leica, Germany) and a ReichertJung Polyvar light microscope $(1000 \times)$ (Leica, Austria). Branchiobdella species were identified using the keys provided by Gelder et al. (1994), Neubert and Nesemann (1999) and Nesemann and Hutter (2002) considering morphological and anatomical characters (e.g. jaw structure). Preserved $H$. chappuisi specimens were identified according to the descriptions of Michaelsen (1926), Pop (1975) and Bunke (1988). Certain morphological and anatomical characters (e.g. ventral ciliary field, position of hair chaetae bundles, number of chaetae per bundle, elliptic insertion arrangement of chaetae) were studied using scanning electron microscopy (images not shown). $N$. communis (Piguet, 1906) determination was performed according to the key provided by Sperber (1950).

\subsection{Record and analysis of abiotic parameters}

At each study site, two litres of surface water were collected in glass bottles and stored in a cooling box during the transport to the laboratory. At brooks where epibionts were 

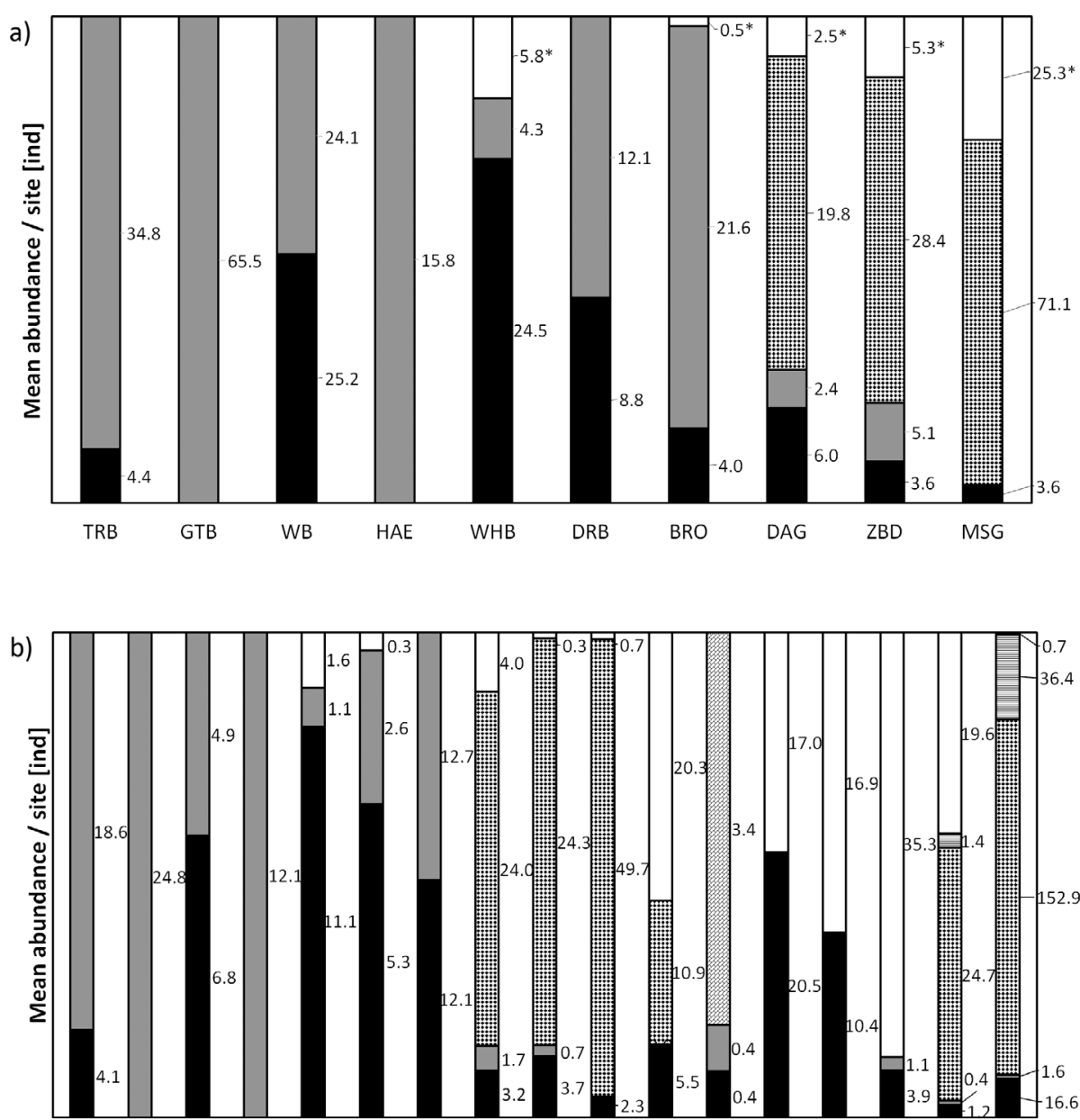

TRB GTB WB HAE WHB DRB BRO DAG ZBD MSG HIN WAS MB CHE RB SEE SLB

Brook

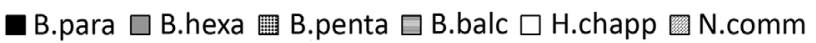

Fig. 3. Species communities found on the stone crayfish in the study area: (a) summer and (b) autumn. Numbers indicate average species abundances at a site based on the mean. B.para =Branchiobdella parasita, B.hexa = Branchiobdella hexadonta, B.penta $=$ Branchiobdella pentadonta, B.balc $=$ Branchiobdella balcanica, H.chapp $=$ Hystricosoma chappuisi, N.comm = Nais communis; for study site abbreviations see Table $1 .{ }^{*}=H$. chappuisi summer abundances are qualitative.

sampled in summer and autumn, water samples were taken in both seasons. Water chemical parameters $(\mathrm{pH}$, conductivity, hardness, alkalinity, $\mathrm{Ca}, \mathrm{Mg}, \mathrm{SO}_{4}, \mathrm{Cl}, \mathrm{NO}_{3}, \mathrm{NH}_{4}, \mathrm{NO}_{2}, \mathrm{PO}_{4}$, $\mathrm{O}_{2}$, DOC) were analysed at the Vorarlberg State Administration laboratories (Bregenz, Austria). Water temperature, $\mathrm{pH}$, conductivity and oxygen concentration were measured in the field using a WTW ProfiLine Oxi 3205 (WTW CellOx 325 sensor) and a WTW Multi 4310 (WTW TetraCon 325 and WTW SenTix 41 sensors) portable instrument. Additionally, at each site water discharge (low, moderate, high) and land use (forest, treelines and farmland, settlement and farmland, farmland) were assessed qualitatively.

\subsection{Data analysis}

Due to significant differences between summer and autumn epibiont abundances (Mann-Whitney $U$-tests, $p \leq 0.05$ ), all statistical analyses were performed separately for summer and autumn data.
For testing species-specific associations of individual epibiont species to certain crayfish body areas, study sites were pooled. Specifically, the abundances of a tested epibiont species from different sites were pooled to a group, when they did not differ significantly (Kruskal-Wallis-test and pairwise Mann-Whitney $U$-tests, $p \leq 0.05$ ) (Tab. S3). Pooling sites based on the abundance of individual species was preferred to the total epibionts abundance, as the location/behaviour of an individual species on the crayfish host might be affected by differences in the total abundance. First, tests were performed with regard to differences between the dorsal and the ventral side of the body (dorsal= $\mathrm{CLD}+\mathrm{CAD}+\mathrm{ABD}$, ventral $=\mathrm{CLV}+\mathrm{CAV}+\mathrm{ABV})($ abbreviations see Sect. 2.2). Furthermore, differences were assessed between claws $(\mathrm{CLW}=\mathrm{CLD}+\mathrm{CLV})$, carapace $(\mathrm{CAR}=\mathrm{CAD}+\mathrm{CAV})$ and abdomen $(\mathrm{ABD}=\mathrm{ABD}+\mathrm{ABV})$. As the data were not normally distributed, all the analyses were performed using the nonparametric Mann-Whitney $U$-tests $(p \leq 0.05)$. Results are only presented when the mean abundance of an individual epibiont species on the crayfish was $\geq 2.5$ ind. (Tab. S3). 
The assessment of relevant ecological factors influencing the abundance of individual epibiont species followed a stepwise approach. First, principal components analysis was used to reduce the number of environmental (water quality) predictor variables. For each epibiont species (dependent variable) the presumably most relevant predictors and coexisting epibiont species were then included in a correlation analysis (Spearman-test, $p \leq 0.05$ ). Different regression models, in which the species abundance was modelled against the included predictors, were tested. Given that host body length and water temperature (DeWitt et al., 2013) as well as water discharge and land use might play a relevant role, these variables were additionally considered in the analyses. The tested regression models were: Poisson, zero-inflated Poisson (ZIP), negative binomial (NegBin) and zero-inflated negative binomial (ZINB). For species recorded at only a few sites, the number of zero counts were too high for running zero-inflated models. Therefore, we additionally applied a logistic regression model, in which the outcome variable is dichotomous. In order to select the most relevant predictors, the stepwise selection was applied in the analyses.

AIC and log-Likelihood values were used to compare the goodness of fit of the different models. In order to test the quality of each model, the modelled abundances were correlated against the abundances of the field records (Spearman-test, $p \leq 0.05$ ). Models with a low AIC/logLikelihood value and a high correlation coefficient were considered best fitting.

All statistical analyses were performed using PASW 21 (IBM, USA) and R-Studio 3.1.0 (R Core Team, 2014). Regression models in R-Studio were run with the following scripts: pscl (Jackman, 2015), Mass (Venables and Ripley, 2002) and boot (Canty and Ripley, 2016) for ZIP and ZINB, foreign (R Core Team, 2015), Mass for Poisson and NegBin and aod (Lesnoff and Lancelot, 2012), Rcpp (Edelbuettel and Francois, 2011) for logistic regression.

\section{Results}

\subsection{Diversity and characteristics of epibiont communities}

Stone crayfish epibionts were recorded at all 17 investigated sites. Over all, four species of Branchiobdella and the polychaete species $H$. chappuisi were found. Additionally, at the site WAS, the oligochaete species $N$. communis was detected on all sampled crayfish specimens. Recorded Branchiobdella species included B. parasita, B. hexadonta, Branchiobdella pentadonta (Whitman, 1882) and Branchiobdella balcanica (Moszynski, 1937). B. parasita and B. hexadonta occurred very frequently (at $88 \%$ and $76 \%$ of the sites, respectively), whereas $B$. pentadonta (35\%) and $B$. balcanica $(12 \%)$ were only present at a few sites. Depending on the site, nearly all crayfish were infested with Branchiobdella $(100 \%$ in summer, $90-100 \%$ in autumn). The polychaete worm $H$. chappuisi was recorded on stone crayfish at 6 out of 10 (summer) and 11 out of 17 (autumn) sites (60\% and 64\%, respectively). The infestation rate of $H$. chappuisi on crayfish specimens at the individual sites ranged from $17 \%$ to $100 \%$.

Over all, eight different unique combinations of taxa were found at the sites (Fig. 3a and b). The number of existing species at a site ranged between one (GTB, HAE) and five (SEE, SLB). The polychaete $H$. chappuisi was recorded in coexistence with Branchiobdella in five different communities (Fig. 3b), which included all of the Branchiobdella species detected in the study area. $N$. communis was observed on crayfish inhabited by $B$. parasita and $B$. hexadonta.

\subsection{Species-specific associations of epibionts to body areas}

The sampling revealed that a large proportion of the $B$. parasita, $B$. pentadonta and B. balcanica specimens can be sampled directly from the crayfish exoskeleton, whereas almost all $B$. hexadonta individuals appeared only after rinsing the crayfishes in the salty bath. Specifically, on average $63 \%$ and $81 \%$ of $B$. parasita specimens, $40 \%$ and $75 \%$ of $B$. pentadonta specimens and $86 \%$ of $B$. balcanica specimens were picked from the body surface of the crayfish (summer and autumn, respectively; $B$. balcanica: autumn). In contrast, only $3 \%$ (summer) and 8\% (autumn) of B. hexadonta specimens were visible on the exoskeleton and thus in both seasons $>90 \%$ remained hidden prior to the salty bath (Tab. S4).

Excluding the unspecific "R", on the crayfish hosts, species-specific associations of Branchiobdella to certain body areas were identified. In most population groups, significantly more B. parasita and B. balcanica specimens were detected on the dorsal part of the crayfish body (Fig. $4 \mathrm{a}$ and d), whereas the opposite was observed for $B$. pentadonta (Fig. 4c). $B$. hexadonta did not display significant differences between the dorsal and the ventral body part (Fig. 4b) (MannWhitney $U$-tests, $p \leq 0.05)$. B. parasita was furthermore most abundant on the carapace, followed by the abdomen and the claws (significant for all but one group, Mann-Whitney $U$ tests, $p \leq 0.05$, Fig. 5a). B. hexadonta specimens were in both population groups most abundant on the carapace (significant in one group) and no significant differences were found between the claws and the abdomen (Mann-Whitney $U$-test, $p$ $\leq 0.05$, Fig. 5 b). B. pentadonta showed a clear association to the claws; in all four population groups the species was significantly more often recorded on this body area than on the carapace and the abdomen (Fig. 5c). For two out of four groups, Mann-Whitney $U$-tests moreover revealed a significantly higher abundance on the carapace than on the abdomen. $B$. balcanica displayed sufficient abundances for statistical tests at only one site (SLB). Here, the species occurred with a significantly higher abundance on the abdomen in comparison to the claws. Differences between the claws and the carapace and between the carapace and the abdomen were not significant (Fig. 5d). For H. chappuisi and N. communis specimens the original position of the specimens on the body could not be determined.

The comparison between sites with different Branchiobdella combinations revealed that the species-specific occupation of preferred areas does not significantly change as a function of co-occurring Branchiobdella species. Regardless of the presence/absence of other Branchiobdella, individual species remained on the body area(s) with the strongest association. Thus, neither did B. parasita specimens show an abundance shift towards the claws at sites where $B$. pentadonta was absent, nor $B$. pentadonta towards the carapace at sites free of B. parasita or B. hexadonta (Tab. S5). 

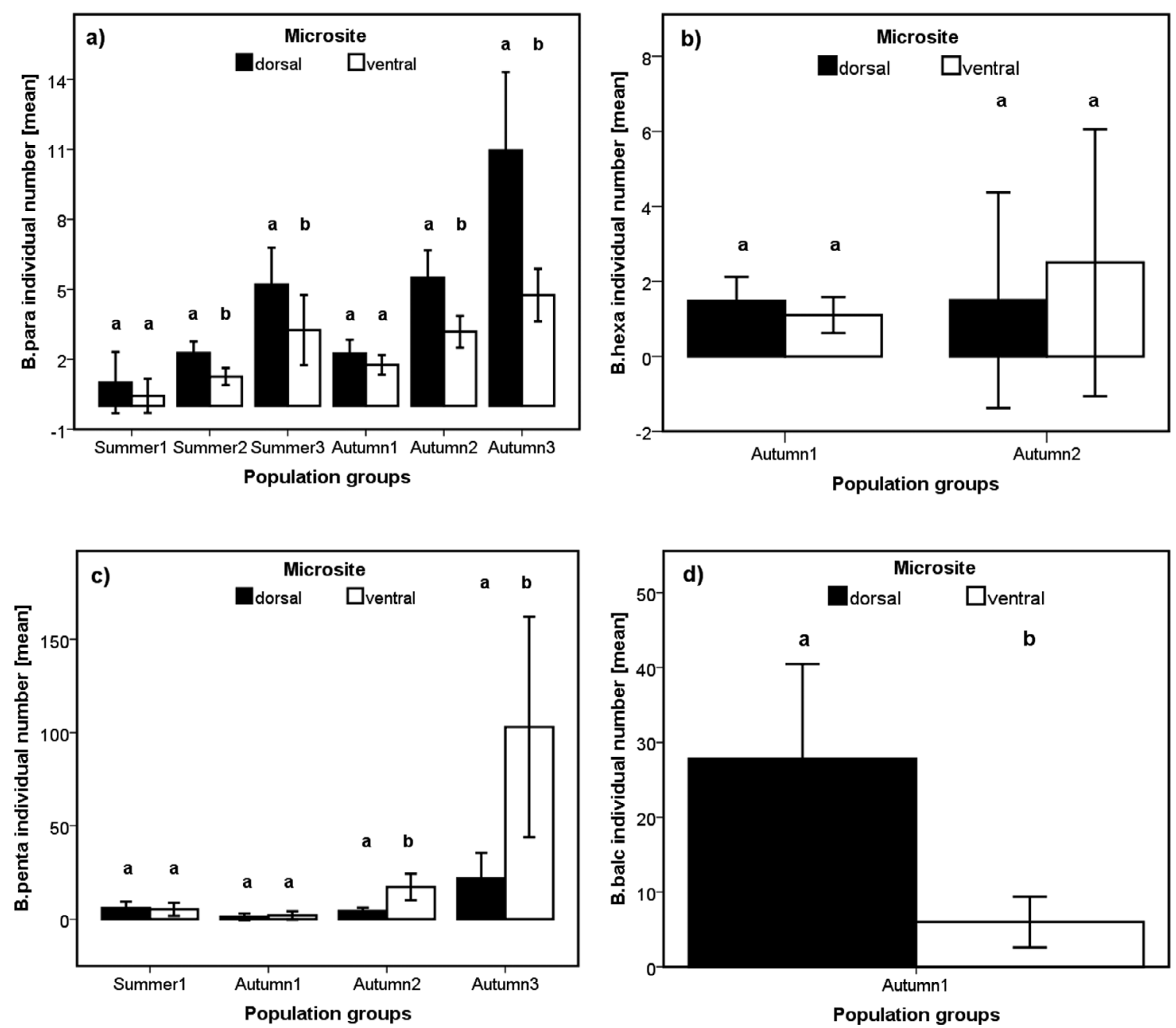

Fig. 4. Branchiobdella species-specific occurrences on the dorsal and ventral side of the crayfish body for the groups of pooled populations (sites) presented in Table S3. For each season (if both seasons were available), groups are in order of increasing mean abundances. Bars marked with the same letter are not significantly different at the $p \leq 0.05$ level by Mann-Whitney $U$-test. For epibiont abbreviations see Figure 3 .

\subsection{Biotic and abiotic factors influencing the abundance and occurrence of Branchiobdella species and $\boldsymbol{H}$. chappuisi}

The total length of the crayfish individuals included in the regression models ranged from 5.0 to $9.8 \mathrm{~cm}$ in both seasons (summer: mean: 7.1, $n=109$; autumn: mean: 7.5, $n=153$ ). Due to high correlations with many water chemical variables (multicollinearity), the factor "land use" was not included in the models. For H. chappuisi, B. parasita and B. hexadonta, model selection suggested that the ZINB model had the best fit (null model). The predictor variables included into the regression analyses are provided for each epibiont species in Table S6.

In the count model component, a significant positive correlation was observed between the abundance of $H$. chappuisi and water temperature and water discharge, whereas the opposite was true for the $\mathrm{PO}_{4}$-concentration. The $\mathrm{NO}_{2}$ concentration only played a significant role in the second model component, where an increase in $\mathrm{NO}_{2}$ decreased the log odds of excess zeros $(p=0.03)$. Likewise, an increase in the water temperature and discharge displayed a decrease in the log odds of excess zeros, while $\mathrm{PO}_{4}$ had the opposite effect. The predicted abundance and the field data abundance were correlated in this model with $R=0.72$ ( $p<0.001$; Tab. 2).

The abundance of $B$. parasita was significantly positively correlated with an increase in the total length of the host (TL) and water discharge in both seasons. In summer, the $\mathrm{PO}_{4}$ - and $\mathrm{Cl}^{-}$concentration had a significantly negative effect on abundance, whereas in autumn the $\mathrm{NO}_{2}$-concentration displayed a strong positive effect. In the zero-inflation models, the log odds of excess zeros were negatively affected by the water discharge in summer and by the $\mathrm{NO}_{2}$-concentration and the TL of the crayfish in autumn (Tab. 2). Overall, the modelled data and the field data were correlated in both summer $(R=0.84, p=0.001)$ and autumn $(R=0.83, p=0.001)$.

The summer abundance of $B$. hexadonta was not only significantly influenced by the abiotic factors $\mathrm{SO}_{4}^{-}$ concentration and water temperature, but also by the biotic factors TL and abundance of co-existing B. pentadonta (Tab. $2)$. An increase in $B$. pentadonta and water temperature decreased the $B$. hexadonta abundance, whereas an increase in $\mathrm{SO}_{4}{ }^{-}$and $\mathrm{TL}$ revealed a positive effect. According to the inflation component, an increase in B. pentadonta and water 


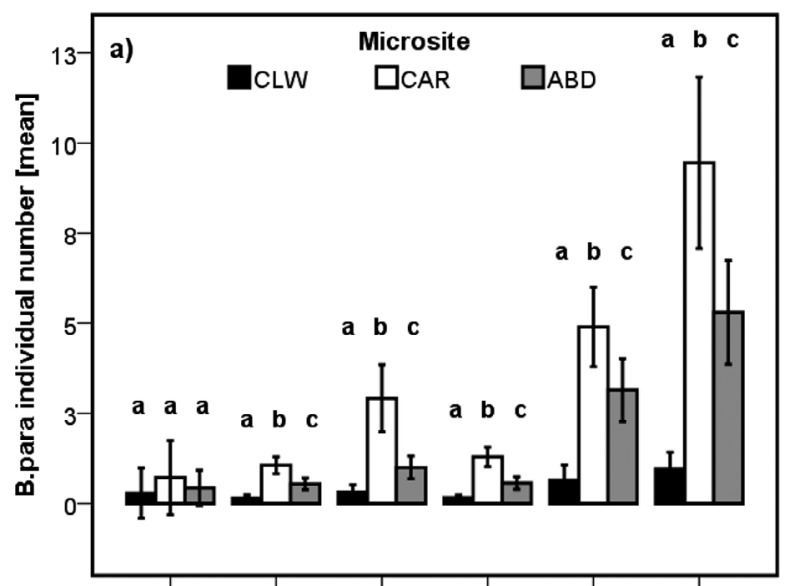

Summer1 Summer2 Summer3 Autumn1 Autumn2 Autumn3 Population groups

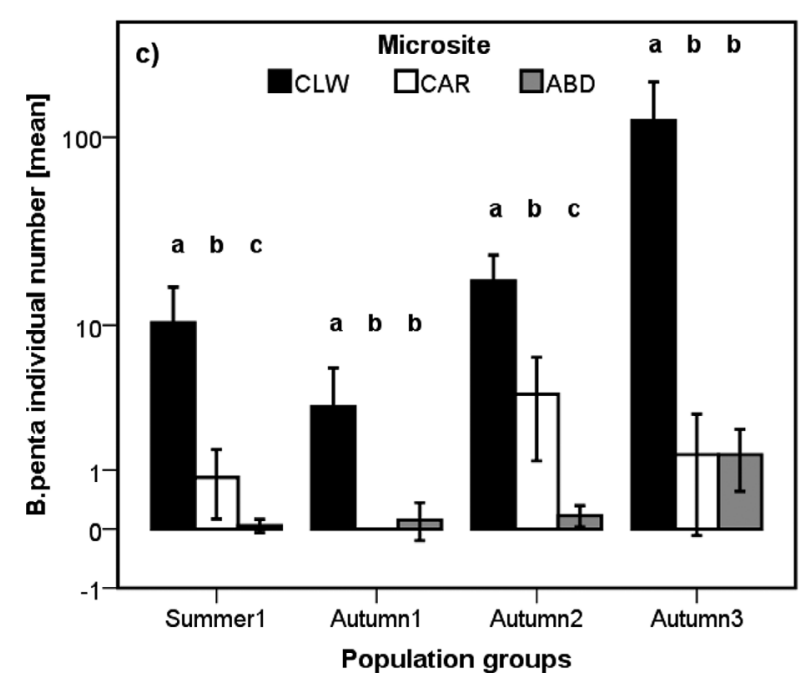

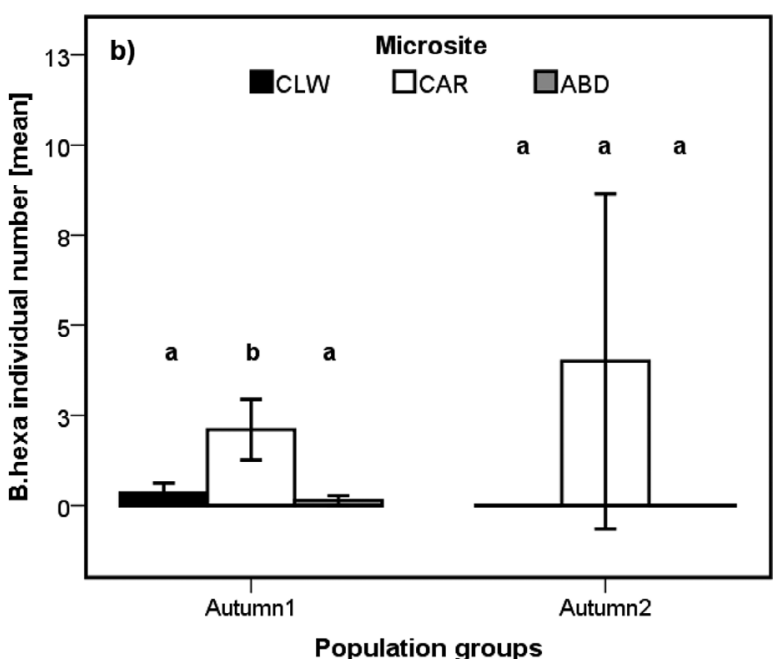

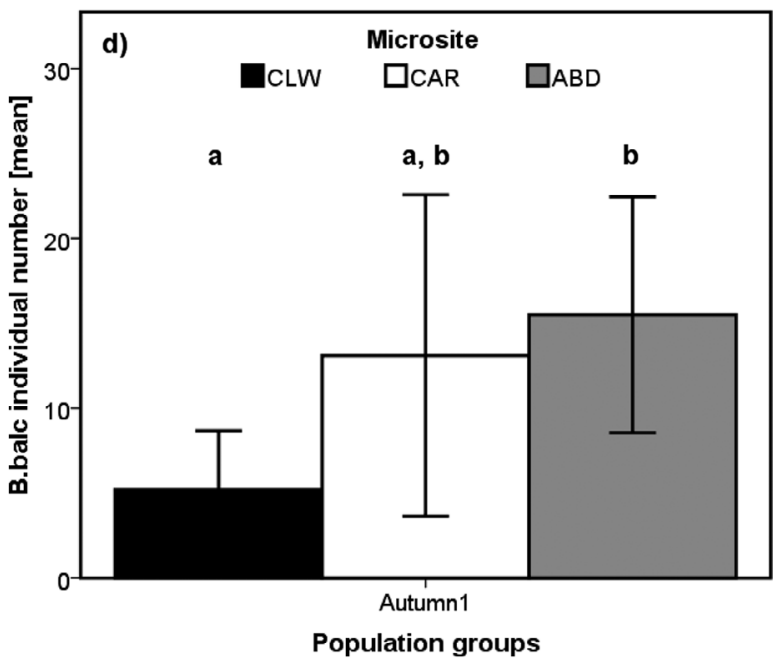

Fig. 5. Branchiobdella species-specific occurrences on different parts of the crayfish body for the groups of pooled populations (sites) presented in Table S3. For each season (if both seasons were available), groups are in order of increasing mean abundances. Bars marked with the same letter are not significantly different at the $p \leq 0.05$ level by Mann-Whitney $U$-test. For epibiont abbreviations see Figure 3 (CLW $=$ claws, $\mathrm{CAR}=$ carapace, $\mathrm{ABD}=$ abdomen $)$.

temperature turned out to significantly increase excess zeros of $B$. hexadonta. In autumn, a significant negative correlation was found between the $B$. hexadonta abundance and the $\mathrm{NO}_{2}-$ concentration as well as the $B$. pentadonta abundance in the count model. The inflation model indicated more excess zeros with an increase in the $\mathrm{NO}_{2}$-concentration and water discharge (Tab. 2).

For $B$. pentadonta and $B$. balcanica, due to a high percentage of zero counts and little variation in the higher counts, the logistic regression model revealed the best data fit. In summer, the occurrence of $B$. pentadonta was mainly explained by the $\mathrm{NO}_{2}$-concentration and TL; while an increase in $\mathrm{NO}_{2}$ significantly increased the chance of $B$. pentadonta to occur, an increase in TL had a reverse effect. In autumn, $B$. pentadonta occurrence was negatively affected by an increase of $B$. hexadonta and the $\mathrm{PO}_{4}$-concentration (Tab. 3).

For $B$. balcanica, the model indicated that an increase in the concentration of dissolved organic carbon (DOC) and the abundance of $B$. pentadonta have a significantly positive effect on the occurrence, whereas an increase in the water temperature negatively affects the probability of the species to occur (Tab. 3).

\subsection{Epibiont biogeographical distribution pattern}

In the study area, certain distribution patterns for the crayfish epibionts were observed. With regard to large Central European catchment areas, B. balcanica was only recorded at the two sites located in the Danube catchment (SEE and SLB, Fig. 1), thus being absent at all the Rhine catchment sites. The highest species numbers (5) of the study were also found at these Danubian sites (SEE and SLB). The northernmost populations in Vorarlberg (DAG, MSG, ZBD), where $B$. pentadonta was most abundant, showed high species numbers as well. In contrast, the species numbers at the southernmost sites in Vorarlberg (TRB, GTB, WB, HAE) were lower (1-2) 
C. Berger and L. Füreder: Knowl. Manag. Aquat. Ecosyst. 2017, 418, 50

Table 2. Zero-inflated negative binomial regression models (ZINB) relating the abundance of epibiont species to biotic and abiotic parameters. Intercept indicates the constant in the model, i.e. the value of the dependent variable if all predictors are zero (water discharge $2=$ moderate, water discharge $3=$ high).

\begin{tabular}{|c|c|c|c|c|c|c|}
\hline Species & Model & Variables & Estimate & Std. error & $Z$ value & $\operatorname{Pr}(>|Z|)$ \\
\hline \multirow[t]{13}{*}{ H. chappuisi - autumn } & \multirow[t]{7}{*}{ Count model } & Intercept & 1.55572 & 0.52826 & 2.945 & 0.0032 \\
\hline & & $\mathrm{NO}_{2}$ & 12.9576 & 16.5139 & 0.785 & 0.4327 \\
\hline & & $\mathrm{PO}_{4}$ & -0.12588 & 0.05690 & -2.212 & 0.0269 \\
\hline & & Temp & 0.19359 & 0.03955 & 4.894 & $<0.001$ \\
\hline & & Water discharge 2 & 0.6098 & 0.4291 & 1.421 & 0.1553 \\
\hline & & Water discharge 3 & 1.0309 & 0.4742 & 2.174 & 0.0297 \\
\hline & & Log (theta) & 0.3963 & 0.2140 & 1.852 & 0.0641 \\
\hline & \multirow[t]{6}{*}{ Zero-inflation model } & Intercept & 7.0359 & 2.4391 & 2.885 & 0.0039 \\
\hline & & $\mathrm{NO}_{2}$ & -492.662 & 224.959 & -2.190 & 0.0285 \\
\hline & & $\mathrm{PO}_{4}$ & 0.16804 & 0.07926 & 2.120 & 0.0340 \\
\hline & & Temp & -0.6242 & 0.19034 & -3.279 & 0.001 \\
\hline & & Water discharge 2 & -0.5001 & 1.07371 & -0.466 & 0.6414 \\
\hline & & Water discharge 3 & -4.5652 & 1.52789 & -2.988 & 0.0028 \\
\hline \multirow[t]{13}{*}{ B. parasita - summer } & \multirow[t]{7}{*}{ Count model } & Intercept & -1.04486 & 0.53786 & -1.943 & 0.0521 \\
\hline & & $\mathrm{PO}_{4}$ & -0.02155 & 0.01033 & -2.086 & 0.0370 \\
\hline & & Crayfish length (TL) & 0.45136 & 0.06957 & 6.488 & $<0.001$ \\
\hline & & $\mathrm{Cl}$ & -0.15038 & 0.06437 & -2.336 & 0.0195 \\
\hline & & Water discharge 2 & 1.21816 & 0.22403 & 5.438 & $<0.001$ \\
\hline & & Water discharge 3 & 1.29285 & 0.24590 & 5.258 & $<0.001$ \\
\hline & & Log (theta) & 1.56041 & 0.27648 & 5.644 & $<0.001$ \\
\hline & \multirow[t]{6}{*}{ Zero-inflation model } & Intercept & -1.3882 & 6.1633 & -0.225 & 0.8281 \\
\hline & & $\mathrm{PO}_{4}$ & -0.1837 & 0.2458 & -0.747 & 0.4549 \\
\hline & & Crayfish length (TL) & -0.2150 & 0.8205 & -0.262 & 0.7933 \\
\hline & & $\mathrm{Cl}$ & 1.7005 & 1.0075 & 1.688 & 0.0915 \\
\hline & & Water discharge 2 & -8.4418 & 4.1981 & -2.011 & 0.0443 \\
\hline & & Water discharge 3 & -1.5799 & 7.9266 & -0.199 & 0.8420 \\
\hline \multirow[t]{11}{*}{ B. parasita - autumn } & \multirow[t]{6}{*}{ Count model } & Intercept & -1.95593 & 0.54941 & -3.560 & $<0.001$ \\
\hline & & $\mathrm{NO}_{2}$ & 49.84228 & 8.52938 & 5.844 & $<0.001$ \\
\hline & & Crayfish length (TL) & 0.38336 & 0.06477 & 5.919 & $<0.001$ \\
\hline & & Water discharge 2 & 0.50787 & 0.18369 & 2.765 & 0.006 \\
\hline & & Water discharge 3 & 0.51977 & 0.21603 & 2.406 & 0.016 \\
\hline & & $\log ($ theta $)$ & 1.24995 & 0.22501 & 5.555 & $<0.001$ \\
\hline & \multirow[t]{5}{*}{ Zero-inflation model } & Intercept & 5.0279 & 1.8525 & 2.714 & 0.006 \\
\hline & & $\mathrm{NO}_{2}$ & -140.0871 & 59.7089 & -2.346 & 0.019 \\
\hline & & Crayfish length (TL) & -0.6878 & 0.2516 & -2.733 & 0.006 \\
\hline & & Water discharge 2 & -0.5071 & 0.6260 & -0.810 & 0.418 \\
\hline & & Water discharge 3 & -0.5389 & 0.7631 & -0.706 & 0.480 \\
\hline \multirow[t]{11}{*}{ B. hexadonta - summer } & \multirow[t]{6}{*}{ Count model } & Intercept & 6.239299 & 1.707913 & 3.653 & $<0.001$ \\
\hline & & B. pentadonta & -0.032697 & 0.006939 & -4.712 & $<0.001$ \\
\hline & & $\mathrm{SO}_{4}$ & 0.172329 & 0.023791 & 7.244 & $<0.001$ \\
\hline & & Temp & -0.347369 & 0.109146 & -3.430 & $<0.001$ \\
\hline & & Crayfish length (TL) & 0.188052 & 0.078316 & 2.401 & 0.016 \\
\hline & & $\log ($ theta $)$ & 0.799737 & 0.168157 & 4.756 & $<0.001$ \\
\hline & \multirow[t]{5}{*}{ Zero-inflation model } & Intercept & -48.68137 & 31.48474 & -1.546 & 0.1221 \\
\hline & & B. pentadonta & 0.09543 & 0.04060 & 2.350 & 0.0188 \\
\hline & & $\mathrm{SO}_{4}$ & -0.74565 & 0.65022 & -1.147 & 0.2515 \\
\hline & & Temp & 3.89572 & 1.98919 & 1.958 & 0.0502 \\
\hline & & Crayfish length (TL) & & & & \\
\hline
\end{tabular}


Table 2. (continued).

\begin{tabular}{|c|c|c|c|c|c|c|}
\hline Species & Model & Variables & Estimate & Std. error & $Z$ value & $\operatorname{Pr}(>|Z|)$ \\
\hline & & & -1.95872 & 1.09983 & -1.781 & 0.0749 \\
\hline \multirow[t]{11}{*}{ B. hexadonta - autumn } & Count model & Intercept & 3.018 & 0.2873 & 10.505 & $<0.001$ \\
\hline & & B. pentadonta & -0.00482 & 0.002256 & -2.136 & 0.03266 \\
\hline & & $\mathrm{NO}_{2}$ & -123.4 & 45.45 & -2.714 & 0.007 \\
\hline & & Water discharge 2 & -0.4092 & 0.3038 & -1.347 & 0.17791 \\
\hline & & Water discharge 3 & -0.07327 & 0.3467 & -0.211 & 0.83261 \\
\hline & & $\log ($ theta $)$ & 0.1464 & 0.2591 & 0.565 & 0.57212 \\
\hline & Zero-inflation model & Intercept & -2.8675 & 0.810892 & -3.536 & $<0.001$ \\
\hline & & B. pentadonta & -0.005950 & 0.005985 & -0.994 & 0.32017 \\
\hline & & $\mathrm{NO}_{2}$ & 221.87867 & 70.524492 & 3.146 & 0.002 \\
\hline & & Water discharge 2 & -0.065808 & 0.658922 & -0.100 & 0.92045 \\
\hline & & Water discharge 3 & 1.751308 & 0.744510 & 2.352 & 0.01866 \\
\hline
\end{tabular}

Table 3. Logistic regression models relating the occurrence of $B$. pentadonta and B. balcanica to biotic and abiotic parameters. B. pentadonta was found in summer and autumn samples, whereas $B$. balcanica only in autumn samples. Intercept indicates the constant in the model, i.e. the value of the dependent variable if all predictors are zero.

\begin{tabular}{|c|c|c|c|c|c|}
\hline Variables & Estimate & Std. error & $Z$ value & $\operatorname{Pr}(>|Z|)$ & Exp. estimate \\
\hline \multicolumn{6}{|c|}{ B. pentadonta - summer } \\
\hline Intercept & 1.6417 & 4.3864 & 0.374 & 0.70820 & 5.164197 \\
\hline $\mathrm{NO}_{2}$ & 1237.6394 & 475.3860 & 2.603 & 0.00923 & Infinite \\
\hline $\mathrm{Cl}$ & -0.2047 & 0.2323 & -0.881 & 0.37819 & 0.814889 \\
\hline Crayfish length (TL) & -1.4261 & 0.5667 & -2.516 & 0.01186 & 0.240245 \\
\hline \multicolumn{6}{|c|}{ B. pentadonta - autumn } \\
\hline Intercept & 6.00449 & 1.80433 & 3.328 & $<0.001$ & 405.24265 \\
\hline $\mathrm{PO}_{4}$ & -0.28642 & 0.06699 & -4.276 & $<0.001$ & 0.750944 \\
\hline B. hexadonta & -0.57036 & 0.15914 & -3.584 & 0.001 & 0.565322 \\
\hline Crayfish length (TL) & -0.34840 & 0.20350 & -1.712 & 0.0869 & 0.705817 \\
\hline \multicolumn{6}{|c|}{ B. balcanica - autumn } \\
\hline Intercept & -10.04137 & 2.57570 & -3.898 & $<0.001$ & 0.000044 \\
\hline DOC & 2.31322 & 0.69835 & 3.312 & $<0.001$ & 10.10691 \\
\hline B. pentadonta & 0.05461 & 0.01622 & 3.367 & $<0.001$ & 1.056129 \\
\hline Temp & -0.63166 & 0.28170 & -2.242 & 0.0249 & 0.531710 \\
\hline
\end{tabular}

and $B$. hexadonta was the most abundant species. H. chappuisi, $B$. pentadonta and $B$. balcanica were not present in any of these populations. In the majority of Swiss populations (western part of study area) $H$. chappuisi was, together with $B$. parasita, highly abundant, whereas $B$. pentadonta was only found at one out of five sites (HIN). Over all, the species diversity in the northern part of the study area was highest.

\section{Discussion}

\subsection{Diversity and characteristics of epibiont communities}

The presented results revealed a large diversity of epibiont communities on the stone crayfish in the study area, which consist of four Branchiobdella species and the polychaete
H. chappuisi. While records of these four Branchiobdella species in the study area were not unexpected due to their wide distribution in Central Europe (Voigt, 1885; Pierantoni, 1912; Karaman, 1970; Nesemann, 1994; Neubert and Nesemann, 1999; Nesemann and Hutter, 2002; Füreder et al., 2009; Vlach et al., 2017), we report here for the first time the occurrence of the polychaete worm H. chappuisi on freshwater crayfish in the Central European Alps. In contrast to sporadic findings of this polychaete in east and southeast Europe (Boshko, 1983; Subchev and Stanimirova, 1986; Subchev et al., 2007) this polychaete is apparently a common part of the stone crayfish epibiont communities in Central Europe. H. chappuisi could possibly be another partner in the crayfish cleaning symbiosis, as described for Branchiobdellida (Brown et al., 2002; Lee et al., 2009), and thus complement the crayfish-Branchiobdellida-microcosm. In fact, the lack of jaws and the presence of 
a ciliary field on the ventral side of the prostomium suggests that the species is not capable of feeding on the hosts tissue, but grazes on the biofilm growing on the crayfish body surface. Accordingly, bacteria, diatoms and detritus have been found in the intestine of $H$. chappuisi (Pop, 1975) and other Aeolosomatidae species were reported to use the ventral surface of the prostomium to ingest small particles off the substrate (Singer, 1978). Based on our findings no conclusions can be made about the interactions between Branchiobdellida and the polychaete worm. However, given that crayfish worms are sporadically predatory (Gelder and Williams, 2015), we cannot rule out that they feed on $H$. chappuisi. Future feeding experiments in the laboratory can elucidate whether such an interaction exists.

No specimens of $B$. papillosa have been found at the site reported by Nesemann and Hutter (2002). Regardless of a recent re-description, which stated the justification of the species despite morphological similarities to $B$. parasita (Subchev and Gelder, 2010), in our opinion a misidentification due to preservation cannot be ruled out and therefore further field samplings are necessary to assure the existence of this recently described species.

Given the preference of $N$. communis for rather low amounts of organic matter and detritus as well as small forested running waters (Nijboer et al., 2004), the occurrence of this oligochaete in $A$. torrentium habitats was not surprising. However, in contrast to typical crayfish epibionts, this species has no anatomical structure allowing the oligochaete to attach to the host's exoskeleton. Since the species has not yet been detected on freshwater crayfish, we did not consider $N$. communis as part of the epibiont community of the stone crayfish.

Regardless of the obtained results, we can not rule out that the stone crayfish in the study area is inhabited by further epibiont species, some of which have been previously detected on freshwater crayfishes. This is particularly true for protozoans (e.g. ciliates, flagellates), which could not be detected with the applied sampling method. In contrast, other taxa reported to occur on Pacifastacus lenuisculus (Dana, 1852) (Cuellar et al., 2002) were not to be expected on $A$. torrentium in the study area as they are not native to European crayfish species. This holds true for instance for Turbellaria (Southern hemisphere), Ostracoda (Australasia, North and Central America) and Acarina (Australia) (for overview see Alderman and Polglase, 2002).

\subsection{Species-specific associations of epibionts to body areas}

With regard to the epibiont assemblages, we obtained remarkable differences among the sites not only concerning species composition, but also relative species abundances. As demonstrated at the two German sites, none of the epibionts strictly outcompetes the others. Such ecological phenomena are often due to the differentiation of specific niches among the co-existing groups (Begon et al., 2006). Given that all European Branchiobdella species are considered to be omnivores that feed on detritus, algae, diatoms or invertebrates (Neubert and Nesemann, 1999; Gelder and Williams, 2015) a specialization in different food sources seems unlikely. The obtained results rather give support to the presumption that species-specific spatial niches enable them to co-exist on the common habitat "crayfish". The fact that B. parasita and B. balcanica display a stronger association to the host's dorsal body areas, whereas $B$. pentadonta is more abundant on the ventral side, represents one aspect of this "niche theory". Whereas the first two species need larger tolerances with regard to higher flow velocities, $B$. pentadonta might benefit from the direct contact to the soil in terms of food sources. $B$. parasita was moreover most abundant on the carapace, but can also have high abundances on the abdomen (Subchev, 2014). $B$. pentadonta specimens were strongly associated to the claws, which is in accordance with the reports of Neubert and Nesemann (1999) and Subchev (2014). Lastly, the large majority of $B$. hexadonta specimens was detected in " $R$ ", which seems to greatly confirm reports in the literature (Pop, 1965; Grabda and Wierzbicka, 1969; Subchev, 2014), that this species is gill-dwelling and has its main occurrence in the branchial cavity. As our tests exhibited that these characteristic distribution patterns of the Branchiobdella species seem not to vary as a function of the presence/absence of other species (Tab. S5), there is evidence that the community with respect to microhabitats is a co-evolutionary unit. Whether or not, $H$. chappusi is part of this co-evolutionary unit, cannot be concluded based on our findings. However, as we detected the polychaete only in "R", it likely inhabits particularly the branchial chamber of the crayfish host (Kasprzak, 1976).

\subsection{Biotic and abiotic factors influencing the abundance and occurrence of Branchiobdella species and $\boldsymbol{H}$. chappuisi}

Based on the obtained results, certain abiotic and biotic parameters could be identified to have an influence on the abundance and occurrence of the investigated crayfish epibionts. The abundance of most species increased with an increase in the nutrients $\left(\mathrm{NO}_{2}, \mathrm{DOC}\right)$ in the water, whereas for $B$. hexadonta the opposite trend was observed. This phenomenon might indicate, that an increase in nutrients can be advantageous for epibionts due to a stronger biofilm growth (Meike, 1999; Vedia et al., 2016), but can, at high doses, also be harmful for certain aquatic species (Stelzer and Joachim, 2010).

A large hosts' body size turned out to be advantageous for the $B$. parasita and B. hexadonta abundance. Such a positive correlation between the crayfish size and the abundance of Branchiobdellida was reported previously for other species (Young, 1966; Scalici et al., 2010). Regardless of recent reports, according to which environmental factors play a larger role for the abundance of B. kozarovi (Subchev, 1978) than the host size (DeWitt et al., 2013), the link between crayfish size and epibionts abundance seems intuitive as large crayfish provide a bigger surface and molt less frequently (Vedia et al., 2016). Moreover, DeWitt et al. did not include small crayfish individuals, and thus a bias in their results cannot be ruled out.

Regarding water temperature and discharge, our results indicated that $H$. chappuisi inhabits both rhithral and potamal stretches of rivers. In contrast, $B$. hexadonta and $B$. balcanica are likely to be sensitive to higher water temperatures, and $B$. hexadonta to high water discharge. This is in accordance with 
previous records of $B$. hexadonta in crenal and epirhithral stretches of rivers (Neubert and Nesemann, 1999), which are on average characterized by a high altitude and low water discharge. Given that B. balcanica was previously detected in potamal river stretches (Neubert and Nesemann, 1999), our results are unexpected, but should be interpreted with caution due to small sample number. Overall, our findings suggest temperature preferences and tolerance ranges of individual species (Berry and Holt, 1959), which likely reflect the distribution of European Branchiobdellida.

The co-existence of other epibionts turned out to be of minor relevance for the abundance of individual epibiont species. Although at first surprising, the existence of speciesspecific niches on the hosts' body is likely to lower interspecific competitive interactions and hence enable species to co-exist. However, as such interactions among North American Branchiobdellida were recently reported to increase at higher densities (Skelton et al., 2016), the minor impact of other epibionts might only be stable at low to moderate densities. Whether or not temporal adaptations, such as species-specific abundance peaks at different times, help species to co-exist has not yet been tested and should therefore be addressed in future research.

\subsection{Epibiont biogeographical distribution pattern}

To the best of our knowledge, we performed the first comprehensive study about the occurrence and distribution of Branchiobdella species in the European Rhine catchment. Considering also our records in the Danube catchment, we were able to notice certain distribution patterns as we hypothesized. The absence of B. balcanica at all 15 Rhine catchment sites strongly supports that this species has no occurrence in this major European catchment area. Although $B$. balcanica was previously suggested to be restricted to the Danube and Elbe catchment (Nesemann, 1994), our intense survey provides valuable data to confirm this. Given that the sampled sites in the Rhine catchment covered a wide range of habitat characteristics (altitude, water quality, flow regime, etc.), ecological factors do not seem to be important for this absence. The strict distribution barrier between the two catchment areas rather suggests that this absence is due to biogeographical reasons, i.e. that the species has never reached the Rhine catchment during the colonization history of its host, the stone crayfish. The present-day distribution of $A$. torrentium was mainly shaped by paleohydrological events and historical cycles of warming and cooling periods (Trontelj et al., 2005; Klobučar et al., 2013). Like numerous plant and animal species (Hewitt, 1999), the stone crayfish was restricted to southeast refuge areas during the last glaciation periods, from where it was re-colonizing Central Europe via the Danube catchment (Holdich, 2002). However, due to a complex recolonization history with several cycles of retreat and spreading in the pre-Pleistocene and Pleistocene as well as possible micro-refugia outside southeast Europe, Central European stone crayfish populations probably do not belong to one single recolonization lineage (Trontelj et al., 2005). In fact, they might originate from different phylogeographic lineages, which have been spreading from their refugial areas along different routes or at different times. Given that a migration connection between the Danube and the Rhine catchment existed only periodically (Keller and Krayss, 2000), the restriction of $B$. balcanica to the Danube catchment could reflect a different phylogeographic origin of stone crayfish populations in the Rhine and Danube catchment area as to which only the lineage in the Danube catchment was inhabited by $B$. balcanica. Only genetic analyses identifying the distribution of phylogenetic lineages of both $B$. balcanica and the stone crayfish in the study area can corroborate this hypothesis. However, recently the existence of stone crayfish micro-refuges has been suggested in the area of the German sites investigated here (Schubart and Huber, 2006; Berger et al., unpubl.), and thus a biogeographic origin of this distribution pattern seems very likely.

With regard to $B$. pentadonta, our field survey revealed a restriction of this species to the northern part of the study area. Taking into account that sites in the East and South were inhabited by other Branchiobdella species, the extinction of this single species seems unlikely. The observed pattern might thus rather reflect that the ecological requirements of $B$. pentadonta were only fulfilled at certain sites. Although it was previously hypothesized that this species is sensitive to low water temperature (Pop, 1965), our regression models did not indicate any link between the water temperature and the occurrence of $B$. pentadonta. Nevertheless, as the southern and eastern parts of the study area were rather mountainous regions with steep slopes, whereas in the north the landscape was flattened, the observed distribution pattern could reflect that this species is restricted to rhithral and potamal stretches of running waters (Karaman, 1970).

Overall, the obtained results indicate that the occurrence of individual species is mainly a result of biogeographical and environmental factors, whereas the abundance is regulated by biotic and abiotic parameters, among which the hosts' body size, nutrient concentration and water temperature and discharge are pivotal.

\subsection{Implications for conservation management}

Several aspects of this research are of relevance for future conservation policies. As previously reported, human-mediated translocations of crayfishes imply not only risks due to the potential invasiveness of the crustaceans themselves (Gherardi, 2007), but also due to the introduction of exotic epibiont species into new habitats (Vedia et al., 2015; James et al., 2017). Likewise, evidence was found here that B. balcanica does not occur naturally in the European Rhine catchment, and thus the introduction of this species should be avoided. In accordance with findings of Berger et al. (unpubl.) with regard to A. torrentium phylogenetics, the Rhine and the Danube catchment should therefore be treated as separate units in the stone crayfish conservation management. Moreover, our results indicate that individual Branchiobdella species and $H$. chappuisi have specific habitat requirements, particularly in terms of water temperature and discharge. Although more research is needed in this field, we advocate that prior to restocking and reintroduction of crayfish into new environments, the epibiont community at the donor site and the suitability of target sites should be tested with regard to habitat conditions. Thorough consideration of the habitat require- 


\section{Berger and L. Füreder: Knowl. Manag. Aquat. Ecosyst. 2017, 418, 50}

ments of the host species as well as the epibiont assemblage can provide the long-term survival of the obligate associates as well as their hosts due to benefits for the mutualistic interaction.

\section{Conclusions}

This research contributes greatly to our understanding of the crayfish-epibiont microcosm and confirmed most of our initial hypotheses. We observed a remarkable diversity of Branchiobdella communities on $A$. torrentium and detected the polychaete species $H$. chappuisi, which was so far not reported in Central Europe. Given its widespread occurrence in the study area, this species appears to be a common part of these communities. Moreover, we identified certain biogeographical and ecological parameters having an influence on the occurrence and abundance of the epibionts, among which the water discharge was not reported so far. Evidence was found that individual Branchiobdella species are strongly associated to certain body areas on the host, which seems to be a result of the co-evolution of the epibiont assemblage. Although further phylogenetic testing is needed, the absence of $B$. balcanica in the Rhine catchment could be linked to the distribution of different phylogenetic lineages of $A$. torrentium in Central Europe. Given the highly complex and obligate relationship between the stone crayfish and its epibionts, we advocate a holistic approach in future conservation policies, which will be to the best of both the crayfishes and their epibionts.

Acknowledgements. We would like to thank the three anonymous reviewers whose comments on the manuscript were helpful and highly appreciated. Furthermore, we are very grateful to Mag. Michael Kugler (Switzerland) and Roland Paravicini (Germany) for sampling permission and advice, Prof. Janette Walde for advice in statistical data analysis and to Dr. Maja Šrut and Assoc. Prof. Steven Weiss for helpful advice on the manuscript.

This study was financially supported by the inatura Erlebnis Naturschau GmbH, Dornbirn, Austria.

Conflicts of interest. The authors declare that they have no conflicts of interest. The study did not include any human participants. Stone crayfish specimens were released again after epibionts sampling, whereas epibionts had to be sacrificed for further investigation.

\section{Supplementary Material}

Tables S1 to S6.

The Supplementary Material is available at https:/www.kmaejournal.org/10.1051/kmae/2017039.

\section{References}

Alderman DJ, Polglase JL. 2002. Pathogens, parasites and commensals. In: Holdich DM, Lowery RS, eds. Freshwater crayfish - biology, management and exploitation. London, UK: Croom Helm Ltd., pp. 167-212.

Begon ME, Harper JL, Townsend CR. 2006. Ecology. John Wiley \& Sons, $750 \mathrm{p}$.
Berger C, Füreder L. 2013. Linking species conservation management and legal species protection: a case study on stone crayfish. Freshw Crayfish 19: 161-175.

Berry JW, Holt PC. 1959. Reactions of two species of Branchiobdellidae (Oligochaeta) to high temperatures and low oxygen tensions. Virginia Agricultural Experimental Station. Virginia Polytechnic Institute and Technical Bulletin 141, pp. 3-11.

Bohl E. 1997. An isolated population of the white-clawed crayfish (Austropotamobius pallipes) in the principality of Liechtenstein. Bull Fr Pêche Piscic 347: 701-712.

Boshko E. 1983. Oligochaetes inhabiting freshwater crayfishes in some waters in Ukraina. Vestn Zool 2: 13-20 (in Russian).

Brown BL, Creed RP, Dobson WE. 2002. Branchiobdellid annelids and their crayfish hosts: are they engaged in a cleaning symbiosis? Oecologia 132: 250-255.

Brown BL, Creed RP, Skelton J, Rollins MA, Farrell KJ. 2012. The fine line between mutualism and parasitism: complex effects in a cleaning symbiosis demonstrated by multiple field experiments. Oecologia 170: 199-207.

Bunke D. 1988. Aeolosomatidae and Potamodrilidae. In: Higgins RP, Thiel H, eds. Introduction to the study of Meiofauna. Washington DC/London: Smithonian Institute Press, pp. 345-348.

Canty A, Ripley B. 2016. boot: Bootstrap R (S-Plus) Functions. R package version 1, pp. 3-18.

Chucholl C, Schrimpf A. 2015. The decline of endangered stone crayfish (Austropotamobius torrentium) in southern Germany is related to the spread of invasive alien species and land-use change. Aquat Conserv 26: 44-56.

Creed RPJ, Lomonaco D, Thomas MJ, Meeks A, Brown BL. 2015. Reproductive dependence of a Branchiobdellidan annelid on its crayfish host: confirmation of a mutualism. Crustaceana 88: 385-396.

Cuellar MC, Garcia-Cuence I, Fontanillas JC. 2002. Description de la zooépibiose de l'ecrevisse signal (Pacifastacus leniusculus, Dana) en astaculture. Bull Fr Pêche Piscic 367: 959-972.

DeWitt PD, Williams BW, Lu Z-Q., Fard AN, Gelder SR. 2013. Effects of environmental and host physical characteristics on an aquatic symbiont. Limnologica 43: 151-156.

Edelbuettel D, Francois R. 2011. Rcpp: seamless R and C++ integration. J Stat Software 40: 1-18.

Evans LH, Edgerton BF. 2002. Pathogens, parasites and commensals. In: Holdich DM, ed. Biology of freshwater crayfish. Oxford: Blackwell Science Ltd., pp. 377-438.

Farrell K, Creed RP, Brown BL. 2014. Preventing overexploitation in a mutualism: partner regulation in the crayfish-branchiobdellid symbiosis. Oecologia 174: 501-510.

Füreder L, Edsman L, Holdich DM, et al. 2006. Indigenous crayfish habitat and threats. In: Souty-Grosset C, Holdich DM, Noël PY, Reynolds JD, Haffner P, eds. Atlas of crayfish in Europe. Paris: Muséum nationale d'Histoire naturelle, pp. 25-47.

Füreder L, Summerer M, Brandstätter A. 2009. Phylogeny and species composition of five European species of Branchiobdella (Annelida: Clitellata: Branchiobdellida) reflect the biogeographic history of three endangered crayfish species. J Zool 279: 164-172.

Füreder L, Gherardi F, Souty-Grosset C. 2010. Austropotamobius torrentium. IUCN Red List of Threatened Species.

Gelder SR, Williams BW. 2011. First distributional study of branchiobdellida (Annelida: Clitellata) in the Smoky Mountains National Park, North Carolina and Tennessee, USA, with a redescription of Cambarincola holostomus Hoffman, 1963. Southeast $N$ 10: 211-220.

Gelder SR, Williams BW. 2015. Clitellata: Branchiobdellida. In: Thorp JH, Rogers DC, eds. Ecology and general biology: Thorp 


\section{Berger and L. Füreder: Knowl. Manag. Aquat. Ecosyst. 2017, 418, 50}

and Covich's freshwater invertebrates. London, UK: Academic Press, pp. 551-563.

Gelder SR, Delmastro GB, Ferraguti M. 1994. A report on branchiobdellidans (Annelida: Clitellata) and a taxonomic key to the species in northern Italy, including the first record of Cambarincola mesochoreus on the introduced American red swamp crayfish. Ital J Zool 61: 179-183.

Gelder SR, Delmastro G, Rayburn N. 1999. Distribution of native and exotic branchiobdellidans (Annelida: Clitellata) on their respective crayfish hosts in northern Italy, with the first record of native Branchiobdella species on an exotic North American crayfish. J Limnol 58: 20-24.

Gherardi F. 2007. Biological invasions in inland waters: an overview. In: Gherardi F, ed. Biological invaders in inland waters: profiles, distribution and threats. Dordrecht, Netherlands: Springer, pp. 3-25.

Grabda E, Wierzbicka J. 1969. The problem of parasitism of the species of the genus Branchiobdella Odier 1823. Pol Arch Hydrobiol 16: 93-104.

Hewitt GM. 1999. Post-glacial re-colonization of European biota. Biol J Linn Soc 68: 87-112.

Holdich DM. 2002. Distribution of the crayfish in Europe and some adjoining countries. Bull Fr Pêche Piscic 367: 611-650.

Holdich DM, Reynolds JD, Souty-Grosset C, Sibley PJ. 2010. A review of the ever increasing threat to European crayfish from nonindigenous crayfish species. Knowl Manag Aquat Ecosyst 11: 394-395.

Holt PC. 1965. The systematic position of the Branchiobdellidae (Annelida: Clitellata). Syst Zool 14: 25-32.

Jackman S. 2015. pscl: Classes and methods for R developed in the Political Science Computational Laboratory, Stanford University. $\mathrm{R}$ package version 1.4.9. Stanford, California: Department of Political Science, Stanford University. URL: http://pscl.stanford. edu/.

James J, Davidson KE, Hunt R, Cable J. 2017. Assessing the invasion potential of non-native branchiobdellidans: experimental studies of survival, reproduction and competition. Knowl Manag Aquat Ecosyst 418: 35.

Karaman M. 1970. Beitrag zur Kenntnis der europäischen Branchiobdelliden (Clitellata, Branchiobdellidea). Int Rev Hydrobiol 55: 325-333.

Kasprzak K. 1976. Contribution to the morphology of Hystricosoma chappuisi Michaelsen 1926, with diagnosis of the genus Hystricosoma Michaelsen 1926 (Aeolosomatidae). Bull Acad Pol Sci 24: 161-169.

Keller O, Krayss E. 2000. Die Hydrographie des Bodenseeraums in Vergangenheit und Gegenwart. Berichte der St Gallischen Naturwissenschaftlichen Gesellschaft 89: 39-56.

Klobučar GIV, Maguire I, Gottstein S, Gelder SR. 2006. Occurrence of Branchiobdellidae (Annelida: Clitellata) on freshwater crayfish in Croatia. Int J Limnol 42: 251-260.

Klobučar GIV, Podnar M, Jelić M, Franjević D, Faller M, Štambuk A, Gottstein S, Simić V, Maguire I. 2013. Role of the Dinaric Karst (western Balkans) in shaping the phylogeographic structure of the threatened crayfish Austropotamobius torrentium. Freshw Biol 58: $1089-1105$.

Kouba A, Petrusek A, Kozák P. 2014. Continental-wide distribution of crayfish species in Europe: update and maps. Knowl Manag Aquat Ecosyst 413: 05.

Lee JH, Kim TW, Choe JC. 2009. Commensalism or mutualism: conditional outcomes in a branchiobdellid-crayfish symbiosis. Oecologia 159: 217-224.
Lesnoff M, Lancelot R. 2012. aod: Analysis of overdispersed data. $R$ package version 1.3. URL: http://cran.r-project.org/package=aod. McManus LR. 1960. Some ecological studies of the Branchiobdellidae (Oligochaeta). Trans Am Microsc Soc 79: 420-428.

Meike E. 1999. The relationship between Branchiobdella spec. (Annelida, Oligochaeta) and its host, the noble crayfish (Astacus astacus L.). Arch Hydrobiol 144: 357-369.

Michaelsen W. 1926. Schmarotzende Oligochäten nebst Erörterungen über verwandtschaftliche Beziehungen der Archioligochäten. Mitt Hamburg Zool Mus Inst 42: 91-103.

Nesemann H. 1994. Die Krebsegel im Gebiet der Oberen Donau (Österreich, Deutschland) mit Bestimmungsschlüssel zu den europäischen Arten (Clitellata, Branchiobdellida). Lauterbornia 19: 79-93.

Nesemann H. 1998. Flusskrebse und Krebsegel (Annelida: Branchiobdellida) - eine Symbiose. In: Eder E, Hödl W, eds. Flusskrebse Österreichs, Stapfia 58. Linz, Austria: OÖ Landesmuseum, pp. 197-204.

Nesemann H, Hutter G. 2002. Krebsegel (Branchiobdellidae: Branchiobdella ODIER, 1823) in Vorarlberg (Österreich) mit einer Neubeschreibung von Branchiobdella papillosa n.sp. Vorarlberger Naturschau 11: 203-214.

Neubert E, Nesemann H. 1999. Annelida, Clitellata. Branchiobdellida, Acanthobdellida, Hirudinea. Heidelberg/Berlin: Spektrum Akademischer Verlag $\mathrm{GmbH}, 170 \mathrm{p}$.

Nijboer RC, Wetzel MJ, Verdonschot PFM. 2004. Diversity and distribution of Tubificidae, Naididae, and Lumbriculidae (Annelida: Oligochaeta) in the Netherlands: an evaluation of twenty years of monitoring data. Hydrobiologia 520: 127-141.

Pierantoni U. 1912. Monografia del Discodrillidae. Annuario Museo Zoologica della Universitá de Napoli 3: 1-28.

Pop V. 1965. Systematische Revision der europäischen Branchiobdelliden (Oligochaeta). Zool Jahrb 92: 219-238.

Pop V. 1975. Was ist Hystricosoma chappuisi Michaelsen (Aeolosomatidae, Oligochaeta)? Mitt Hamburg Zool Museum Inst 72: 75-78.

R Core Team. 2014. R: A language and environment for statistical computing. Vienna, Austria: R Foundation for Statistical Computing. URL: http://www.R-project.org/.

R Core Team. 2015. foreign: Read Data Stored by Minitab, S, SAS, SPSS, Stata, Systat, Weka, dBase, .... R package version 0.8-66. URL: http://CRAN.R-project.org/package=foreign.

Scalici M, Di Giulio A, Gibertini G. 2010. Biological and morphological aspects of Branchiobdella italica (Annelida: Clitellata) in a native crayfish population of central Italy. Ital $J$ Zool 77: 410-418.

Schubart CD, Huber MGJ. 2006. Genetic comparisons of German populations of the stone crayfish, Austropotamobius torrentium (Crustacea: Astacidae). Bull Fr Pêche Piscic 380-381: 1019-1028.

Singer R. 1978. Suction-feeding in Aeolosoma (Annelida). Trans Am Microsc Soc 97: 105-111.

Skelton J, Doak S, Leonard M, Creed RP, Brown BL. 2016. The rules for symbiont community assembly change along a mutualismparasitism continuum. J Anim Ecol 85: 843-853.

Souty-Grosset C, Reynolds JD. 2009. Current ideas on methodological approaches in European crayfish conservation and restocking procedures. Knowl Manag Aquat Ecosyst 01: 394-395.

Sperber C. 1950. A guide for the determination of European Naididae. Zoologiska Bidrag från, Uppsala 29: 45-78.

Stelzer RS, Joachim BL. 2010. Effects of elevated nitrate concentration on mortality, growth, and egestion rates of Gammarus pseudolimnaeus amphipods. Arch Environ Contam Toxicol 58: 694-699. 


\section{Berger and L. Füreder: Knowl. Manag. Aquat. Ecosyst. 2017, 418, 50}

Subchev MA. 2007. Branchiobdellidans (Annelida: Clitellata) found in the crayfish and Annelid collections of the Natural History Museum of Humboldt University, Berlin, Germany. Acta Zool Bulg 59: 275-282.

Subchev MA. 2011. First record of Branchiobdella Odier, 1823 (Annelida: Clitellata) in Albania and an overview of the geographic distribution of Branchiobdella hexodonta Gruber, 1882 in Europe. Acta Zool Bulg 63: 109-112.

Subchev MA. 2014. The genus Branchiobdella Odier, 1823 (Annelida, Clitellata, Branchiobdellida): a review of its European species. Acta Zool Bulg 66: 5-20.

Subchev MA, Gelder SR. 2010. Branchiobdellida (Annelida: Clitellata) found in the crayfish collection of the Natural History Museum in Vienna, Austria, with a re-description of Branchiobdella papillosa Nesemann \& Hutter, 2002. Acta Zool Bulg 62: 33-42.

Subchev MA, Stanimirova LS. 1986. The epibiont on crayfishes Hystricosoma chappuisi Michaelsen 1926 (Oligochaeta, Aeolosomatidae) - new species for Bulgarian Fauna. Acta Zool Bulg 9: 518 (in Bulgarian).

Subchev MA, Koutrakis E, Perdikaris C. 2007. Crayfish epibionts Branchiobdella sp. and Hystricosoma chappuisi (Annelida: Clitellata) in Greece. Bull Fr Pêche Piscic 387: 59-66.
Trontelj P, Machino Y, Sket B. 2005. Phylogenetic and phylogeographic relationships in the crayfish genus Austropotamobius inferred from mitochondrial COI gene sequences. Mol Phylogenet Evol 34: 212-226.

Vedia I, Oscoz J, Rueda J, Miranda R, García-Roger EM, Baquero E, Gelder SR. 2015. An alien ectosymbiotic branchiobdellidan (Annelida: Clitellata) adopting exotic crayfish: a biological co-invasion with unpredictable consequences. Inland Waters 5 : 89-92.

Vedia I, Oscoz J, Baquero E. 2016. Invading the invaders: relationships of an exotic branchiobdellidan with its exotic host and environmental conditions. Inland Waters 6: 54-64.

Venables WN, Ripley BD. 2002. Modern applied statistics with S, 4th ed. New York: Springer, 495 p.

Vlach P, Šrámková L, Fialová K, Nováková K. 2017. The occurrence of branchiobdellidans on the stone crayfish (Austropotamobius torrentium) in the Czech Republic. Knowl Manag Aquat Ecosyst. 418: 39.

Voigt W. 1885. Untersuchungen über die Varietätenbildung bei Branchiobdella varians. Arbeiten aus dem Zoologischen Zootomischen Institut in Würzburg 7: 300-368.

Young W. 1966. Ecological studies of the Branchiobdellidae (Oligochaeta). Ecology 47: 571-578.

Cite this article as: Berger C, Füreder L. 2017. Annelid symbiont assemblage and European stone crayfish - a deterministic relationship with implications for conservation management. Knowl. Manag. Aquat. Ecosyst., 418, 50. 